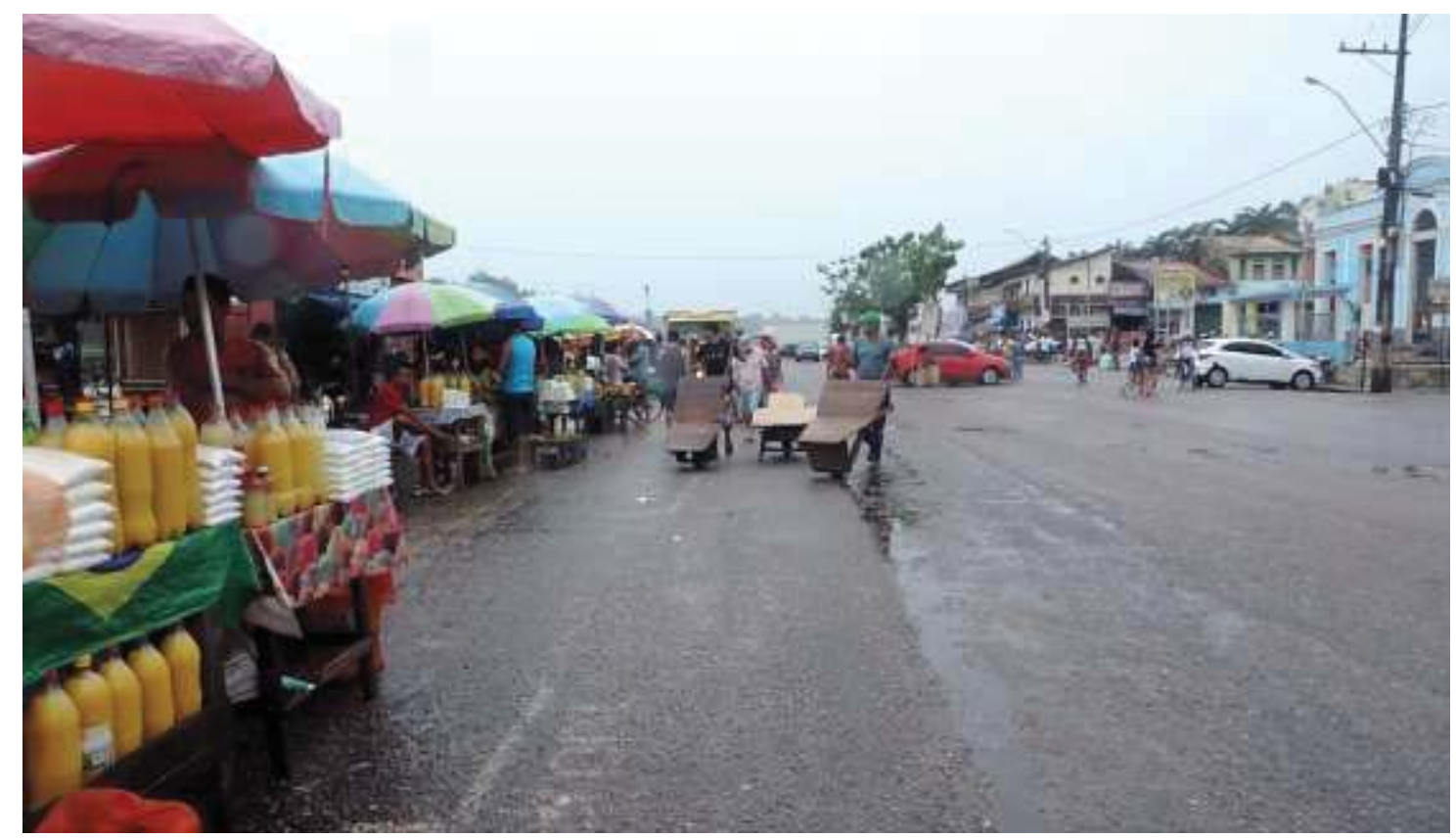

\title{
SABERES, FAZERES E SABORES: O AMANHECER DA FEIRA LIVRE BRAGANTINA
}

\section{KNOW, DO AND TASTE: THE DAWN OF THE FREE TRADE FAIR}

\author{
Samuel A S do Rosario e Jocenilda P S do Rosario
}

SINOPSE: Este vídeo apresenta o amanhecer na feira livre bragantina, mostrando as diversidades de saberes, fazeres e sabores que se encontram neste ambiente, em um dia do mês de março de 2017, a partir da lógica da feira livre. Utilizam-se no vídeo vários espaços da feira livre, no município de Bragança/Pará, entre eles, da farinha e seus derivados, de pescados e mariscos, de frutas e legumes, de produtos artesanais e medicinais oriundos das florestas e dos rios. Na captura das imagens, foi usada uma máquina Nikon Coolpix P520.

SYNOPSIS: This video presents the dawn in the free trade fair of Bragantina, showing the diversities of knowledge, crafts and flavors that are in this environment, one day of the month of March 2017, from the logic of the fair. In the video, several spaces of the fair are used, in the municipality of Bragança / Pará, among them, flour and its derivatives, fish and shellfish, fruit and vegetables, handicrafts and medicinal products from forests and rivers. In capturing the images, a Nikon Coolpix P520 camera was used.

PALAVRAS-CHAVE: Saberes; Fazeres; Sabores; Feira

KEYWORDS: You know; Do it; Flavors; Market-place

\section{FICHA TÉCNICA:}

Produção: Samuel A S do Rosario e Jocenilda P S do Rosario

Imagens/Operador de Câmera: Samuel A S do Rosario

Edição: Samuel A S do Rosario

Roteirista/Texto: Samuel A S do Rosario e Jocenilda P S do Rosario

CREDITS:

Production: Samuel A S do Rosario e Jocenilda P S do Rosario 
Images/Cameraperson: Samuel A S do Rosario

Edition: Samuel A S do Rosario

Scriptwriter/Text: Samuel A S do Rosario e Jocenilda P S do Rosario

LINK PARA ACESSO:

https://youtu.be/FMMFj9u-C5Y 